\title{
QUALIDADE AMBIENTAL DO RESERVATÓRIO CAJÁ, MUNICÍPIO DE TABOLEIRO GRANDE (RN)
}

\author{
Environmental quality of Cajá reservoir, Taboleiro Grande (Rio Grande do Norte State)
}

\author{
Francisco Ericardo do Nascimento \\ Graduado em Geografia Universidade do Estado do Rio Grande do Norte \\ ericado.nascimento@hotmail.com
}

Josiel de Alencar Guedes

Professor Doutor do Curso de Geografia da Universidade do Estado do Rio Grande do Norte josielguedes@uern.br

Artigo recebido em 15/11/2015 e aceito para publicação em 01/03/2016

DOI: $10.12957 /$ tamoios.2016.19610

Resumo

Abstract
O reservatório Cajá é o manancial responsável por abastecer a cidade de Taboleiro Grande, mas, atualmente, sofre com alguns problemas relacionados ao uso e ocupação do entorno, além da diminuição do volume em função da baixa precipitação pluviométrica na região do Alto Oeste Potiguar. O objetivo deste trabalho foi realizar uma análise da qualidade ambiental do reservatório Cajá, localizado no município de Taboleiro Grande (RN). A metodologia consistiu em leituras dos parâmetros de qualidade de água com aparelho multiparâmetro, levantamentos pontuais de impactos ambientais, e entrevistas com a população local sobre questões relacionadas ao uso e qualidade das águas do reservatório, tendo como principal foco a percepção ambiental dos munícipes. Os parâmetros utilizados para analisar a qualidade das águas foram: Temperatura, $\mathrm{pH}$, Oxigênio Dissolvido e Condutividade Elétrica. Estabeleceram-se dois pontos no reservatório, onde as leituras foram realizadas em dois períodos sazonais, sendo uma na estação seca e outra na chuvosa. Os resultados das análises mostraram que o OD foi o parâmetro que apresentou valores mais preocupantes acima do índice estabelecido pelo CONAMA 357/2005 para o consumo da água para o ser humano. A partir do desenvolvimento da pesquisa foi observado que as principais fontes que contribuem para a degradação da qualidade da água do manancial são; o lançamento de esgoto à céu aberto para o interior do reservatório, a criação de animais nas vertentes, e o escoamento de água do cemitério público para a superfície do manancial.

Palavras-chave: Qualidade de água; Uso e ocupação; Impactos ambientais.

The Cajá reservoir is the source responsible for supplying the city of Taboleiro Grande, but currently suffers from some problems related to the use and occupation of the environment, in addition to decreased volume due to low rainfall in the "Região do Alto Oeste Potiguar. The aim of this study was to analyze the environmental quality of Cajá reservoir, located in the municipality of Taboleiro Grande $(\mathrm{RN})$. The methodology consisted of readings of water quality parameters with multiparameter device, specific surveys of environmental impacts, and interviews with local people on issues related to the use and quality of the reservoir water, focusing mainly on the environmental awareness of citizens. The parameters used to analyze the quality of water were: temperature, $\mathrm{pH}$, Dissolved Oxygen and Electrical Conductivity. They set up two points in the reservoir, where the readings were held in two seasonal periods, one in the dry season and one in the wet. The analysis results showed that the OD was the parameter that showed more concern values above the level set by CONAMA 357/2005 for the consumption of water for humans. From the development of the research it was observed that the main sources that contribute to the degradation of source water quality are; the open the discharge of sewage into the reservoir, breeding in the areas, and the flow of water from the public cemetery for the spring surface.

Key-words: Water quality; Use and occupation; Environmental impacts. 


\title{
INTRODUÇÃO
}

A qualidade ambiental de reservatórios é importante e indispensável para aqueles que se utilizam das águas desses mananciais, uma vez que a água é um bem primordial e insubstituível para a sobrevivência humana. Nestas condições, é importante que sua presença no ambiente esteja em qualidade e quantidade apropriadas para sua posterior utilização (ESTEVES, 1998; BRAGA et al., 2002; REBOUÇAS, 2002).

\begin{abstract}
A importância da água não está relacionada apenas às suas funções na natureza, mas ao papel que exerce na saúde, economia e qualidade de vida humana. Apesar da importância que os recursos hídricos exercem para o desenvolvimento regional, a qualidade e a quantidade das águas dos rios vêm sendo cada vez mais afetadas pela ocupação desordenada da bacia hidrográfica. O crescimento demográfico e o desenvolvimento social e econômico aumentam a demanda por água e provocam alterações de ordem física, química e biológica nos ecossistemas aquáticos (SOUZA et al, 2014, p. 30).
\end{abstract}

$\mathrm{Na}$ atualidade, entende-se que a finalidade do uso da água deixou de ser apenas para abastecimento de populações humanas, mas também, passou a ser usada para outros fins como a produção industrial, a irrigação da agricultura e a dessedentação animal, por exemplo. Além disso, o crescimento demográfico e o desenvolvimento social e econômico fizeram com que a demanda por água aumentasse drasticamente provocando, assim, alterações de ordem física, química e biológicas nos ecossistemas aquáticos, ocasionados, dentre outros fatores, pelo uso na irrigação para agricultura e produção industrial de maneira desordenada.

A consequência direta deste uso desordenado é observada na qualidade da água, apresentando-se cada vez mais comprometida. O uso inadequado do solo e da água, a falta de tratamento de esgoto, o aumento de resíduos sólidos jogados em lagos, rios e reservatórios, contribui para a deterioração da qualidade da água, principalmente por falta de tratamento de efluentes, assim como a ocupação desenfreada nas margens e assoreamento, são problemas que têm criado riscos de abastecimento a populações, haja vista que a oferta de água potável do planeta é pequena, e quando não utilizada de forma correta pela população, torna-se mais escassa em relação a sua demanda.

O uso inadequado do solo e da água, a falta de tratamento de esgoto, o aumento de resíduos sólidos jogados em lagos, rios e reservatórios, contribui para a deterioração da qualidade da água, principalmente por falta de tratamento de efluentes. A ocupação desenfreada nas margens e assoreamento são problemas que têm gerado riscos de abastecimento a populações, haja vista que a oferta de água potável do planeta é pequena, e quando não utilizada de forma correta pela população, torna-se ainda mais escassa em relação a sua demanda.

Atividades econômicas associadas à expansão urbana, indústria, serviços e agropecuária, podem ser consideradas fontes de conflitos relativos ao uso da água, associadas ao uso inadequado das margens e desmatamento das matas ciliares. Esses fatores podem provocar modificações na qualidade da água de forma que a exploração de qualquer manancial pode ficar comprometida temporária ou definitivamente (MOTA, 1981).

Associado à importância vital para a manutenção das cidades do semiárido, os reservatórios destacam-se como reserva hídrica no espaço nordestino, incluindo-se o território norte-rio-grandense. Dessa forma, abordam-se nesse trabalho, as questões ambientais e as ações antrópicas que exercem influência sobre a qualidade das águas de 
um manancial localizado no município de Taboleiro Grande (RN), além da percepção ambiental e uso da água dos munícipes.

Para tanto, analisou-se a qualidade das águas do reservatório Cajá associando-a a possíveis fontes como a criação de animais próxima a vertente do reservatório, escoamento de água do cemitério, como também o lançamento de esgoto a céu aberto para o interior da superfície do Cajá, esses fatores são os principais causadores para poluição das águas do manancial, bem como a percepção que os moradores têm sobre o mesmo.

\section{MATERIAIS E MÉTODOS}

O presente trabalho foi desenvolvido no município de Taboleiro Grande $(\mathrm{RN})$, situado no estado do Rio Grande do Norte, na mesorregião do Alto Oeste Potiguar e na microrregião de Pau dos Ferros. Seus limites territoriais apresentam ao Norte o município Itaú (RN), ao sul Portalegre (RN) e Francisco Dantas (RN), ao leste, Riacho da Cruz (RN) e ao oeste do município de Rodolfo Fernandes e São Francisco do Oeste (RN). Sua área territorial abrange $124,1 \mathrm{~km}^{2}$ o qual é equivalente a $0,21 \%$ da superfície do território estadual. Sua sede apresenta altitude de 147 metros e está a $372 \mathrm{~km}$ Natal (RN), capital do Estado (IBGE, 2010).

O clima é caracterizado como muito quente e semiárido e seu período chuvoso é de fevereiro a maio. A temperatura média do município apresenta mínima de $21,0^{\circ} \mathrm{C} \mathrm{e}$ máxima de $36,0^{\circ} \mathrm{C}$; a média anual de umidade relativa do ar é de $66 \%$ e apresenta 2.700 horas de insolação durante o ano. O município encontra-se inserido nos domínios da bacia hidrográfica Apodi-Mossoró. Os principais tributários são os riachos da Estrela, do Cipó e do Tigre. O reservatório público Cajá está localizado nas imediações da área urbana de Taboleiro Grande e tem um volume de acumulação de $942.480 \mathrm{~m}^{3}$ (IDEMA, 2008).

Em relação a metodologia, para a busca de subsídios necessários à análise da qualidade ambiental do reservatório, foram realizados estudos teóricos e empíricos. Para alcançar os objetivos expostos, seguiram-se algumas etapas. Na primeira etapa, foi realizado um levantamento bibliográfico, com base em referenciais teóricos que abordavam temáticas relacionadas à importância e qualidade de água (SELBORNE, 2001; BASSOI, 2005; ROLIM et al, 2013).

$\mathrm{Na}$ etapa seguinte foi realizada uma busca e coleta de dados secundários, especificamente relacionados à exploração de documentos, mapas e fotos sobre o município e o reservatório. $\mathrm{Na}$ sequência foram construídos mapas temáticos de localização.

Foi elaborado um questionário qualitativo com questões abertas e semiabertas e aplicado a 100 moradores da zona urbana do município, representando $10 \%$ da população, cujo objetivo foi a aquisição de dados primários e informações a respeito da percepção ambiental dos munícipes em relação ao reservatório estudado, sendo estes escolhidos segundo a sua disponibilidade em responder e maior idade legal.

Com o auxílio do GPS foram estabelecidos dois pontos para leitura de amostras de no reservatório Cajá (figura 1). 


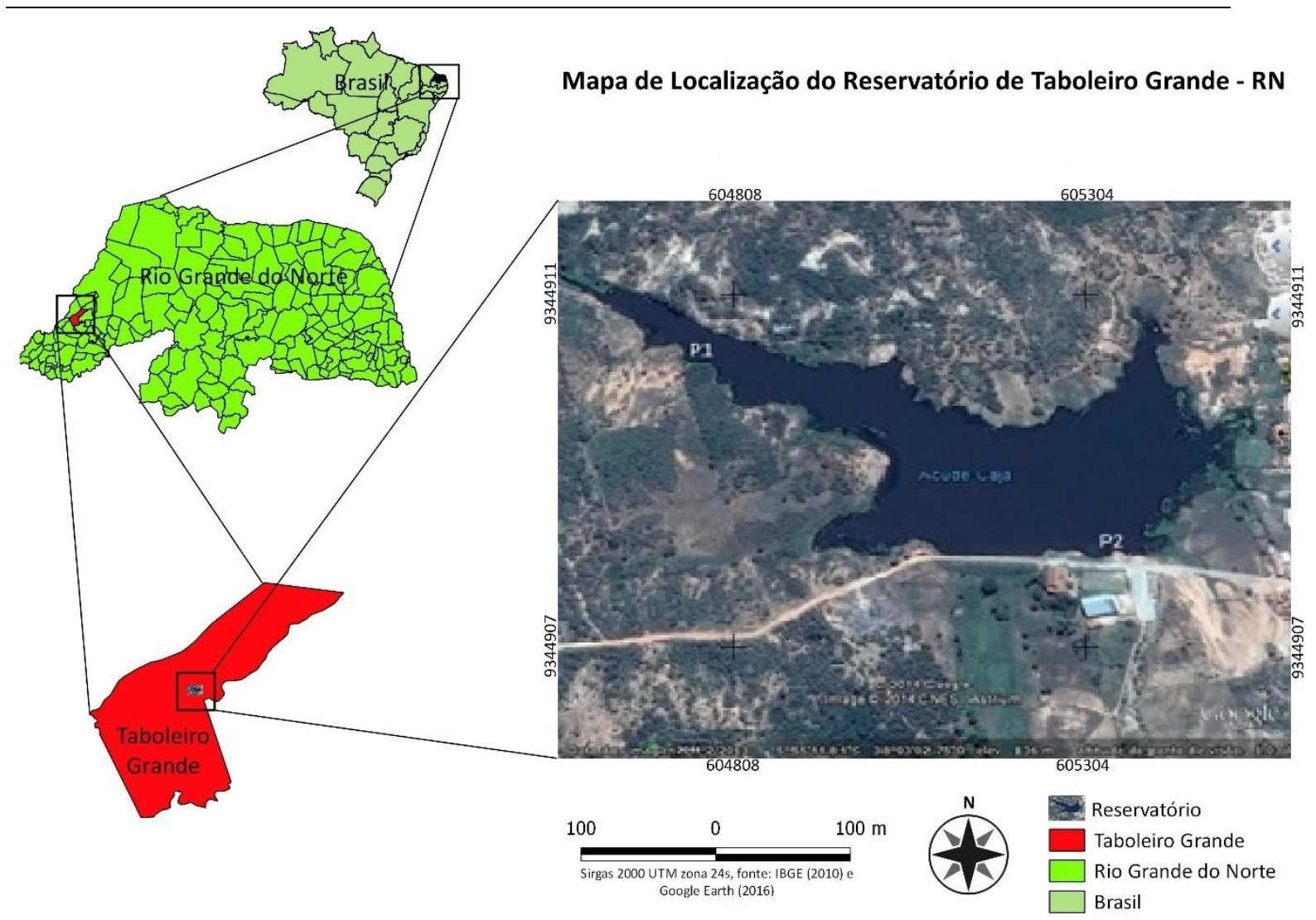

Figura 1: Mapa de localização do reservatório Cajá e dos pontos de leituras dos parâmetros. Fonte: Elaborado a partir do Google Earth.

As leituras foram realizadas nos meses de dezembro de 2014, março e maio de 2015 com auxílio do aparelho Multiparâmetro AKSO modelo SK751, para os seguintes parâmetros: Temperatura $\left(\mathrm{T}^{\circ}\right)$, Oxigênio Dissolvido (OD), pH (potencial Hidrogeniônico) e Condutividade Elétrica (CE). A partir dos dados obtidos foi realizada uma análise comparativa com os parâmetros e padrões de águas estabelecidos pelo CONAMA (2005), para classe 2. As datas das leituras foram estabelecidas em períodos sazonais diferentes, onde o manancial apresentou diferentes volumes de água no reservatório.

\section{RESULTADOS E DISCUSSÃO}

Problemas relacionados ao uso no entorno

O uso irregular e a ocupação inadequada das margens de reservatórios vêm causando grande preocupação em função de problemas que podem acarretar ao manancial. Diante disto, a Resolução do Conselho Nacional de Meio Ambiente (CONAMA) n.302/2002, defende a elaboração do Plano Ambiental de Conservação e Uso do Entorno de Reservatório Artificial, assegurando a função ambiental das Áreas de Preservação Permanente (APP) e seu entorno. Este instrumento legal é importante, pois pode contribuir para a redução dos impactos causados nos recursos hídricos, no solo e na biodiversidade, minimizando os riscos ao bem-estar das populações humanas residentes na área (CONAMA, 2002). 
A qualidade das águas de mananciais superficiais e subterrâneos está diretamente ligada à qualidade de vida da população que se utiliza desse recurso, ou seja, se a qualidade da água não é própria ao consumo pode gerar riscos de contaminação e de doenças advindas de substâncias nocivas encontradas na água. Para Selborne (2001, p.50) "a saúde humana depende do suprimento de água potável segura, adequada, acessível e confiável".

A população residente do município de Taboleiro Grande tem ressalvas ao uso das águas do reservatório, devido a sua proximidade com a zona urbana. Além disso, algumas atividades socioeconômicas em seu entorno aumentam a desconfiança dos munícipes sobre a qualidade ambiental do reservatório. Por causa dessa desconfiança em relação à água, o abastecimento para consumo sempre foi realizado a partir de carros pipas, trazida de reservatórios de outros municípios circunvizinhos. Dessa forma, à água do Cajá sempre foi destinada apenas para a irrigação e para algumas atividades domésticas.

Durante as visitas a área de estudo, foram identificadas algumas possíveis fontes de poluição do manancial, onde os mesmos, segundo relatos da população, contribuem para a degradação da qualidade da água.

Dentre essas fontes poluentes destacam-se o lançamento de esgoto domiciliar a céu aberto aliado as fossas sépticas (Figura 2), responsáveis por escoamento in natura de efluentes para o manancial. Bassoi (2005) aponta que as principais fontes de poluição das águas pelos seus mais diversos usos, podem ser agrupadas da seguinte maneira: poluição natural; poluição devida aos esgotos domésticos; poluição devida aos efluentes industriais e poluição devida à drenagem de áreas agrícolas e urbanas.

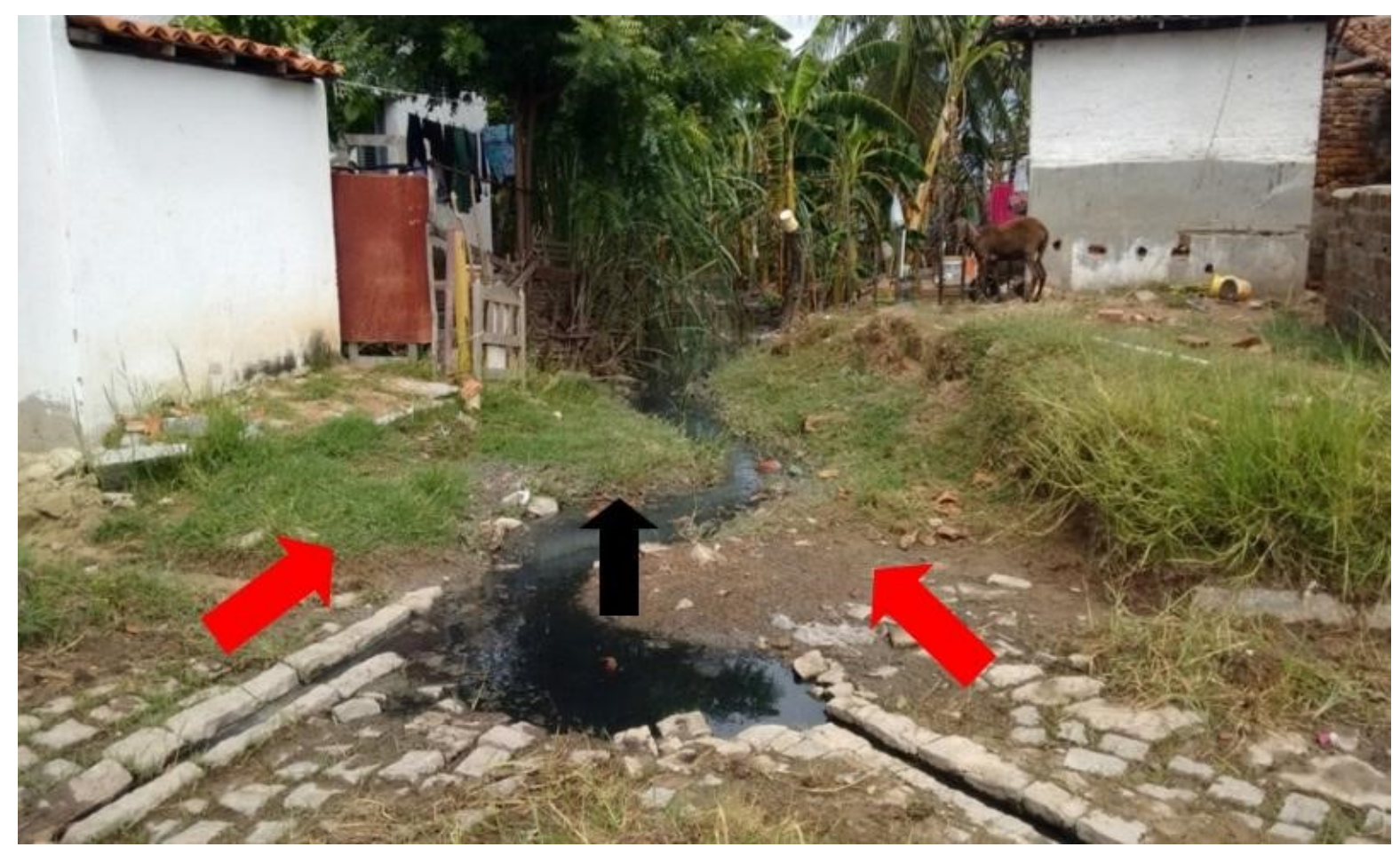

Figura 2: Escoamento de esgoto doméstico (seta em vermelho). A seta de cor preta indica o sentido da drenagem para o reservatório. Fonte: Ericardo Nascimento (2015)

Nos casos de possíveis fontes de poluição ambiental no município, o esgoto é o foco mais visível de poluição em relação à qualidade da água do Cajá. Observou-se que o escoamento de esgoto a céu aberto vai de encontro ao reservatório. $\mathrm{O}$ lançamento "in 
natura" de esgotos domésticos, águas residuais de criatórios de animais e de agroindústrias são as principais fontes de poluição de lagos, canais, rios e mares, segundo (STRUJAK; VIDAL 2007).

O cemitério público municipal (Figura 3), localizado numa vertente, pode ser considerado, também, uma possível fonte de poluição. Os cemitérios são considerados atividades urbanas potencialmente contaminantes, pois através do necrochorume transportado pela água das chuvas infiltradas nas covas ou pelo contato dos corpos com a água subterrânea, podem provocar problemas hidrogeoambientais, ou seja, a contaminação do solo e das águas subsuperficiais (lençóis freáticos) (FURTATO; FURTATO; CRESPI, 2009).

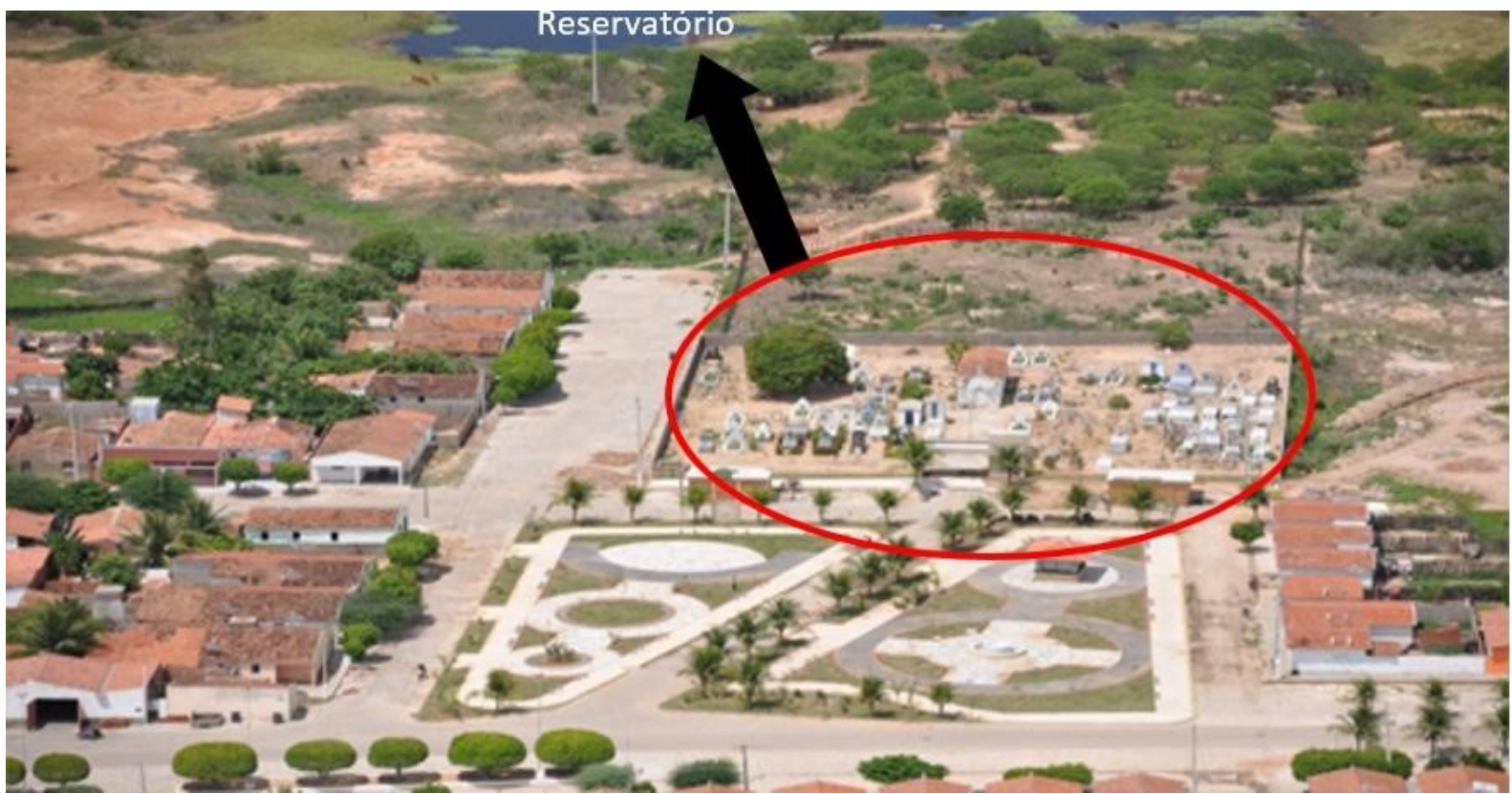

Figura 3: Cemitério público municipal (círculo em vermelho). A seta indica o sentido da drenagem para o reservatório. Fonte: Blog Taboleiro Grande News, 2015.

Segundo Migliorini et. al. (2006), alguns impactos ambientais relacionados às águas subterrâneas podem ser oriundos de cemitérios, considerando que a decomposição dos corpos libera um liquido tóxico chamado necrochorume. Esse líquido caracteriza-se por ser mais viscoso que a água, de cor acinzentada e acastanhada, com cheiros acres e fétidos, e são constituídos por $60 \%$ de água, 30\% de sais minerais e $10 \%$ de substancias orgânicas degradáveis. Dessa forma podem representar alto risco de contaminação durante a decomposição dos corpos. Assim, quando as águas são atingidas pelo necrochorume, podem ser contaminadas por bactérias heterotróficas, proteolíticas, clostrídios sulfitoredutores, enterovírus e adenovírus. Há também um grande consumo de oxigênio, devido à decomposição biológica e as transformações químicas, principalmente dos produtos com nitrogênio, fósforo, enxofre e outros (MATOS, 2001; NOGUEIRA; JUNIOR; COIMBRA, 2013).

Outra possível fonte identificada foram os criatórios de animais nas proximidades do reservatório, com destaque para criação de caprinos, suínos e bovinos (Figura 4). A criação de animais domésticos, especialmente aqueles de grande porte, quando criados em confinamentos, produzem grande quantidade de dejetos, gerando uma provável carga de coliformes, que podem contribuir para a degradação de mananciais, com efeitos que refletem no desequilíbrio ecológico e redução dos níveis de oxigênio 
dissolvido na água, disseminação de microrganismos patogênicos e contaminação das águas (SEGANFREDO, 2000).

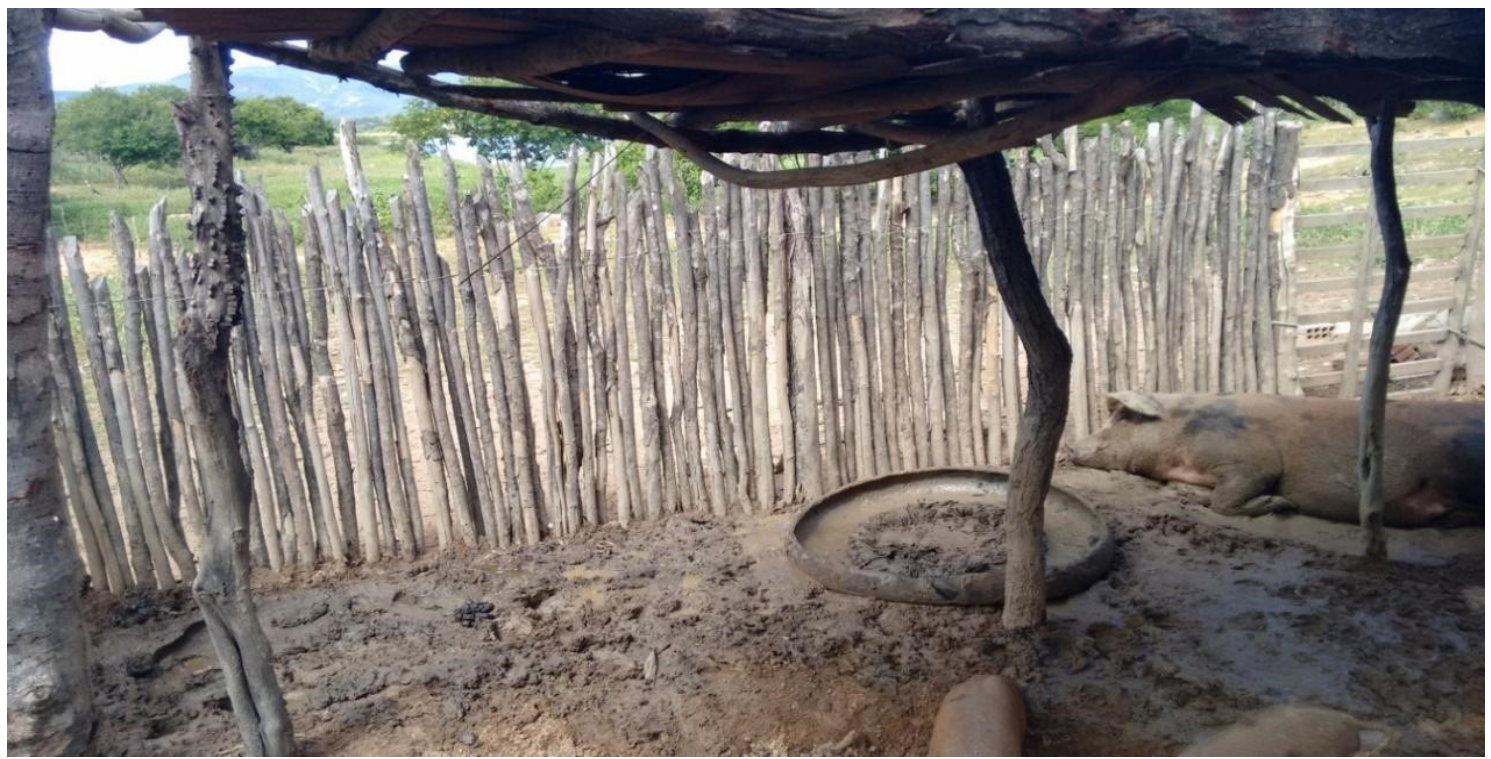

Figura 4: Criatório de suínos nas imediações do reservatório. Fonte: Ericardo Nascimento (2015).

De acordo com Seganfredo (2000), a poluição ambiental causada pelos dejetos suínos é considerada uma atividade de grande potencial poluidor, devido ao elevado número de contaminantes presentes, causando uma forte degradação do ar, do solo e principalmente dos recursos hídricos (águas superficiais e subterrâneas). Os principais constituintes dos dejetos suínos que afetam as águas superficiais são matéria orgânica, nutrientes e bactérias fecais (CAPOANE et al, 2014). Já os que afetam águas subterrâneas são nitratos e bactérias (DARTORA et al, 1998; NOLASCO et al, 2005).

A maior problemática na criação de suínos está na grande produção e lançamento de dejetos não tratados em rios, lagos e no solo, podendo provocar doenças (verminoses, alergias, hepatite), além de trazer desconforto à população (proliferação de insetos e mau cheiro) e ainda provocar impactos ambientais como a morte de peixes e animais, toxidades em plantas e eutrofização dos cursos de água (PEREIRA; DEMARCHI; BUDIÑO, 2009).

Percepção do uso das águas

Em relação ao uso da água do reservatório Cajá, a população sempre teve receio em consumir a água do mesmo. Perguntados se já utilizaram a água do reservatório, os moradores foram unânimes em relatar que usavam, mas enfocando que o uso era apenas para higiene pessoal e doméstica. É o que mostra as afirmações abaixo:

"Uso para lavar louças (afazeres domésticos) porque só serve pra isso" (M.F.A.; Feminino, 58-65 anos).

"Uso apenas para banho e lavar roupas, não há ingerimos porque considero inadequada para este fim" (J.J.A.; Masculino, 26-33 anos). 
"Lutas diárias, lavar louça, roupa, enfim na limpeza" (K.K.F.D.; Feminino, 26-33 anos).

"Sim, para tomar banho e usos domésticos, pois era nossa única fonte de água" (A.A.B.; Masculino, 34-41 anos).

No que diz respeito à qualidade das águas do reservatório, ao questionar se a água é de boa qualidade, percebeu-se que não há confiança dos moradores em relação à mesma, sendo os principais motivos dessa desconfiança, os impactos gerados pela própria população no reservatório. Os impactos percebidos no entorno do reservatório, vão de encontro ao que preconiza a resolução 001/86 do CONAMA, que define impacto ambiental como,

Qualquer alteração das propriedades físicas, químicas e biológicas do meio ambiente, causada por qualquer forma de matéria ou energia resultante das atividades humanas que, direta ou indiretamente, afetam a saúde, a segurança e o bem estar da população; as atividades sociais e econômicas; a biota; as condições estéticas e sanitárias do meio ambiente; a qualidade dos recursos ambientais (CONAMA, 1986).

Sobre considerar a água do reservatório de boa qualidade, as respostas indicam que há certa negativa em utilizá-la, associando a alguns fatores que podem degradar essas águas, conforme pode ser visualizada nas afirmações abaixo:

"Não, porque quando chove a água que escorre do cemitério vai todo pra dentro dele" (C.J.D.A).

"Não, pois não é limpa e nem tratada" (L.L.Q.P.; Feminino, 18-25 anos).

"Não, por diversas irregularidades, como lixo ao redor, banho de animais e não tem tratamento adequado" (L.B.P.; Masculino, 18-25 anos).

"Não, porque tem indícios de dejetos que são depositados nesse reservatório" (J.L.D.; Feminino, 18-25 anos).

"Não. Um dos principais motivos que a água não seja de qualidade são os esgotos do município ser encanado para dentro do mesmo" (D.H.G.S.; Masculino, 26-33 anos).

A partir das respostas dos moradores sobre a qualidade da água, percebeu-se que os problemas dos possíveis focos de poluição encontrados no entorno do reservatório, como também visíveis na cidade e no decorrer das visitas a campo, estão intimamente ligados na desconfiança na qualidade da água do manancial e visível nas respostas dos moradores no questionário. Entende-se, portanto, que a população tem consciência de suas ações sobre o reservatório, mas, pelo fato de não usarem as águas do manancial, não se veem obrigados a preservar as águas e o entorno do reservatório.

Uma curiosidade em relação aos focos de poluição era saber da população se, de alguma forma, o cemitério local influenciava na qualidade das águas do reservatório.

A implantação de cemitérios sem levar em consideração os critérios geológicos e geomorfológicos (características litológicas e estrutura do terreno) e hidrogeológicos (nível do lençol freático), constitui mais uma das causas de deterioração da qualidade das 
águas subterrâneas, pois substâncias provenientes da decomposição de cadáveres podem ter acesso às mesmas, representando um risco do ponto de vista sanitário e higiênico (MARTINS et al, 1991).

Perguntados se o cemitério poderia causar algum tipo de impacto ou influência na qualidade das águas do reservatório, mesmo sem nenhum conhecimento científico sobre o assunto, os moradores foram unânimes em relatar que sim, que a qualidade da água é influenciada pela relação da proximidade e localidade do cemitério e o reservatório. É perceptível isso em suas afirmações abaixo:

"Sim, porque quando chove as infiltrações do solo vão para as águas que correm para dentro" (M.A.P.G.; Feminino, 18-25 anos).

"Sim, porque quando chove a água que fica dentro do cemitério escorre para dentro do açude" (E.N.S.N.; Feminino, 18-25 anos).

"Com certeza, toda água da chuva que escoa do cemitério cai dentro do açude deixando mais contaminado" (F.B.F.N.; Feminino, $42-49$ anos).

"Não tenho dúvidas que a água é também contaminada pelas águas do cemitério" (A.A.B.; Masculino, 34-41 anos).

"Acredito que sim, pois a água é filtrada no solo e por ser tão próxima, pode ser que cause algum dano na sua qualidade" (J.J.A.; Masculino, 26-33 anos).

Análises dos parâmetros

A tabela 1 mostra os resultados de acordo com as leituras realizadas no multiparâmetro em águas do reservatório. Os gráficos da figura 5 dispõem dos dados obtidos através das coletas realizadas em campo durante a pesquisa no reservatório Cajá. Neles estão contidos os resultados de 03 (três) coletas realizadas em dois pontos, coletados em horários aproximados, mas, em períodos sazonais diferentes.

Tabela 1: Parâmetros físico-químicos analisados das amostras de águas coletadas

\begin{tabular}{|c|c|c|c|c|c|c|}
\hline \multirow{2}{*}{ Parâmetros } & \multicolumn{3}{|c|}{ Ponto 1 (P1) } & \multicolumn{3}{c|}{ Ponto 2 (P2) } \\
\cline { 2 - 7 } & $\begin{array}{c}\text { Dezembro } \\
\mathbf{1}^{\circ} \text { Coleta }\end{array}$ & $\begin{array}{c}\text { Março } \\
\mathbf{2}^{\circ} \\
\text { Coleta }\end{array}$ & $\begin{array}{c}\text { Maio } \\
\mathbf{3}^{\circ} \text { Coleta }\end{array}$ & $\begin{array}{c}\text { Dezembro } \\
\mathbf{1}^{\circ} \text { Coleta }\end{array}$ & $\begin{array}{c}\text { Março } \\
\mathbf{2}^{\circ} \\
\text { Coleta }\end{array}$ & $\begin{array}{c}\text { Maio } \\
\mathbf{3}^{\circ} \\
\text { Coleta }\end{array}$ \\
\hline Temperatura & $30,0^{\circ} \mathrm{C}$ & $31,5^{\circ} \mathrm{C}$ & $30,4^{\circ} \mathrm{C}$ & $37,0^{\circ} \mathrm{C}$ & $31,8^{\circ} \mathrm{C}$ & $31,0^{\circ} \mathrm{C}$ \\
\hline pH & 7,75 & 7,84 & 7,76 & 7,76 & 7,6 & 7,74 \\
\hline $\mathbf{C E}$ & 412 & 410 & 378 & 409 & 421 & 449 \\
\hline OD & 2,62 & 5,05 & 4,44 & 4,48 & 5,75 & 5,71 \\
\hline
\end{tabular}

Fonte: Dados coletados a partir da leitura de campo. 


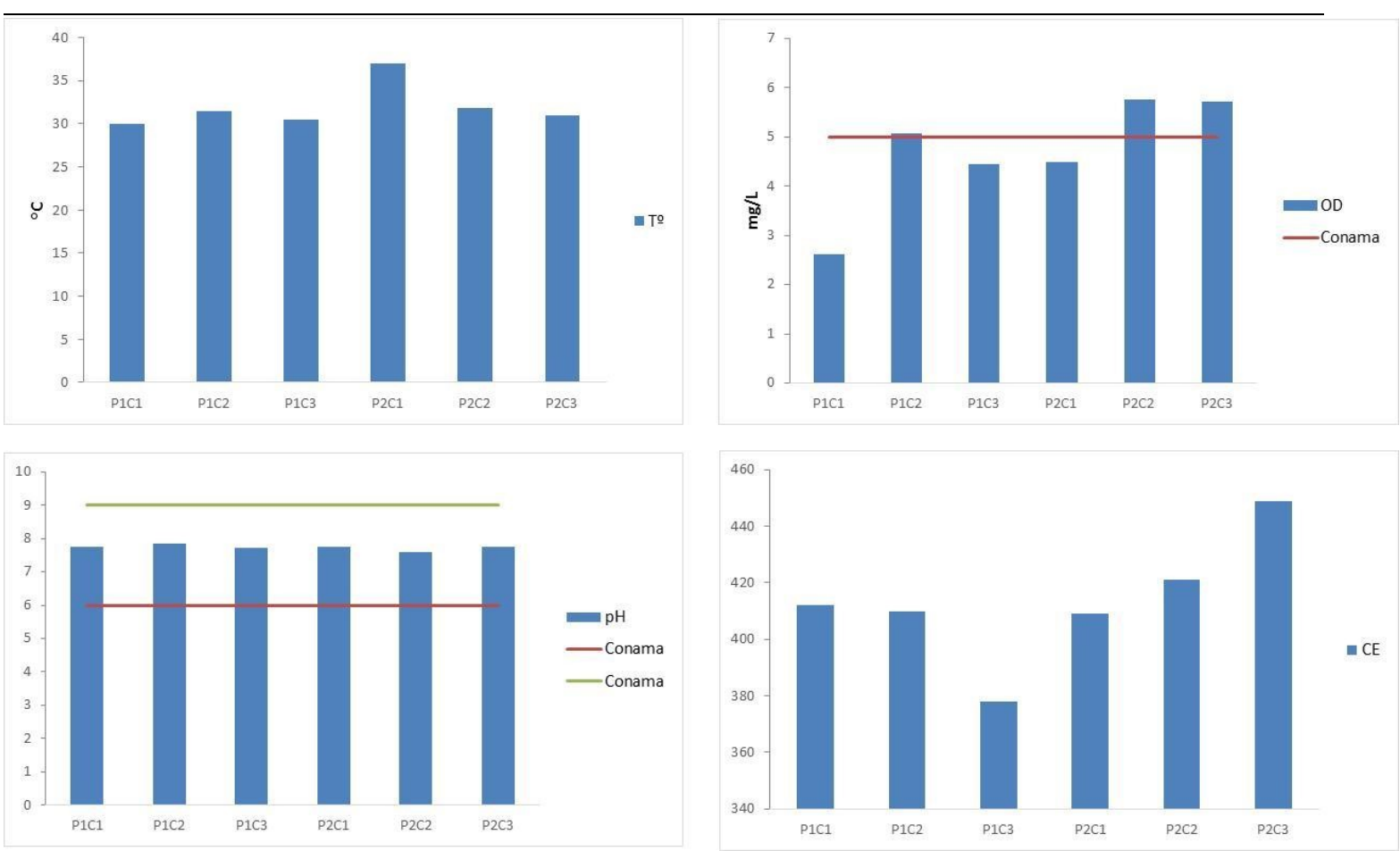

Figura 05: Gráficos dos parâmetros obtidos a partir da leitura no multiparâmetro.

A temperatura pode ser considerada a característica mais importante do meio aquático, pois pode influenciar nas concentrações dos demais parâmetros físicos da água, dentre os quais a densidade, viscosidade, pressão de vapor, bem como a solubilidade dos gases dissolvidos (TUCCI, 2004). No entanto, a Resolução n 357 (CONAMA, 2005) não estabelece limites para esse parâmetro, mesmo sendo extremamente importante para a manutenção da vida aquática.

Verificou-se que a temperatura no reservatório apresentou uma variação brusca entre os dois pontos de monitoramento, apresentando temperaturas de mínima de $30,0^{\circ} \mathrm{C}$ e a máxima de $37,0^{\circ} \mathrm{C}$, mantendo-se uma média constante entre os pontos e as coletas de $31,95^{\circ} \mathrm{C}$. A maior temperatura apresentada de $37,0^{\circ} \mathrm{C}$ no ponto 02 (dois), na primeira coleta, é explicado pela hora em que foi coletada a amostra, às $9 \mathrm{~h} 56 \mathrm{~min}$, quase uma hora acima da primeira coleta no ponto 01(um), coletado precisamente as $9 \mathrm{~h} 00 \mathrm{~min}$, ou seja, a partir da análise feita é perceptível que a temperatura permaneceu constante nos 02 (dois) pontos e nas 03 (três) coletas feitas.

O potencial hidrogeniônico é que determina a acidez ou alcalinidade da água, definindo o comportamento de outros parâmetros, como os metais pesados. Seu valor para a água pura a $25^{\circ} \mathrm{C}$ é igual a 7 e varia entre 0 e 7 , em meios ácidos, e entre 7 e 14 , em meios alcalinos (ROLIM et al, 2013).

$\mathrm{O} \mathrm{pH}$ é importante porque muitas reações químicas que ocorrem no meio ambiente são intensamente afetadas pelo seu valor. Sistemas biológicos são bastante sensíveis ao valor do $\mathrm{pH}$, sendo que, usualmente, decorrentes da atividade humana despejadas no meio aquático podem alterar significativamente o valor do $\mathrm{pH}$, como as disposições ácidas provenientes da poluição atmosféricas (BRAGA, 2005. p.77).

Os teores de $\mathrm{pH}$ não apresentaram oscilação considerável, pois o recomendado pela resolução 357/2005 (CONAMA, 2005) estão na faixa de 6,0-9,0. Valores fora dessa 
faixa podem alterar a qualidade da água. As leituras mostraram que o parâmetro $\mathrm{pH}$ apresentou uma média constante entre todas as coletas e nos dois pontos coletados de 7,74. Dessa forma, o parâmetro está na média instituída pela resolução 357/2005 (CONAMA, 2005).

O teor de oxigênio dissolvido na água é um indicador de suas condições de poluição por matéria orgânica. Assim, uma água não poluída (por matéria orgânica) deve estar saturada de oxigênio. Por outro lado, teores baixos de oxigênio dissolvidos podem indicar que houve uma intensa atividade bacteriana decompondo matéria orgânica lançada na água (MOTA, 1995).

Do ponto de vista ecológico, o parâmetro OD é uma variável extremamente importante, pois é necessário para a respiração da maioria dos organismos que habitam o meio aquático. Geralmente o OD se reduz ou desaparece quando a água recebe grandes quantidades de substâncias orgânicas biodegradáveis encontradas, por exemplo, no esgoto doméstico e em certos resíduos industriais. Ou seja, a redução dos níveis de oxigênio dissolvido pela poluição orgânica é decorrente da atividade dos organismos aeróbios que utilizam o oxigênio, na respiração, para a oxidação da matéria orgânica biodegradável. Este processo é chamado de Demanda Bioquímica de Oxigênio (CARNEIRO, 2002).

Um dos fatores que contribui para reduzir a concentração de OD é a presença de matéria orgânica e nutrientes, principalmente nitrogênio amoniacal, uma vez que os organismos aeróbios presentes degradam esses compostos, consumindo o oxigênio presente no meio. Sabe-se que, quanto maior o valor da demanda bioquímica de oxigênio (DBO) do corpo hídrico, maior será o consumo de oxigênio para eliminação de matéria orgânica biodegradável, levando à menor concentração de OD nesse corpo hídrico, reduzindo sua disponibilidade para fauna e flora presentes. Dessa forma, para que haja um ambiente em equilíbrio é preciso que haja altos valores de OD (oxigênio dissolvido) e baixos valores de DBO (ROLIM et al, 2013).

A partir da coleta feita no reservatório Cajá, o parâmetro OD se mostrou inferior aos limites estipulados pelo CONAMA, no ponto $01(2,62 \mathrm{~mm} / 1$, ) valor muito abaixo do limite da resolução 357/2005. No ponto 01 (um), das três coletas realizadas teve-se em duas ocasiões valores abaixo do preconizado pela resolução, diferentemente do ponto 02 (dois) que em duas coletas se mostram acima. Essa variação pode estar associada a pouca quantidade de água, aliado a grande presença de matéria orgânica, o que faz com que haja uma DBO (Demanda Bioquímica de Oxigênio) maior e, portanto, o lançamento de esgoto, o escoamento das águas do cemitério incorporado com o necrochorume e o lançamento de resíduos dos criatórios de animais para dentro do reservatório são os principais fatores que impactam na poluição hídrica do manancial, esses fatores explicam a diminuição da quantidade de oxigênio da água do mesmo, o que fez com que os níveis de OD fossem abaixo da norma.

A condutividade elétrica representa a quantidade de sais existentes na coluna de água, ou seja, ela é a capacidade que a água tem de conduzir corrente elétrica. Está relacionada com a concentração de íons dissolvidos no corpo de água. Portanto, quanto maior a concentração desses íons dissolvidos, maior o valor da condutividade elétrica. A resolução CONAMA 357/2005 não estabelece valores concretos referentes à condutividade elétrica para o recurso hídrico. A condutividade elétrica da água aumenta à medida que mais sólidos dissolvidos são adicionados, onde altos valores podem indicar caraterísticas corrosivas da água gerados pelo uso irregular do solo ou ainda pela falta de estudo quanto sua aptidão para o uso (SILVA, 2009).

Segundo Mosca (2003), um dos fatores que pode contribuir para a alteração da condutividade elétrica dá água é o despejo de fertilizantes e defensivos agrícolas, que 
acabam aumentando as concentrações iônicas nos corpos d'água, assim como também o aporte de resíduos provenientes da criação de bovinos e suínos (TUNDISI, 1998). Além desses, destaca-se ainda a falta da mata ciliar, pois a mesma exerce forte influência na redução desse parâmetro, já que ela absorve íons dissolvidos (TUNDISI, 1998).

A partir das leituras, a condutividade elétrica foi o parâmetro mais alarmante em relação aos parâmetros considerados normais para os reservatórios. A variação foi bem acima da média considerada normal, em todas as coletas feitas e nos 02 (dois) pontos houve variações entre $378 \mu \mathrm{s} / \mathrm{cm}$ a $449 \mu \mathrm{s} / \mathrm{cm}$. Níveis superiores a $100 \mu \mathrm{s} / \mathrm{cm}$ indicam ambientes impactados, o que se conclui que tais níveis são explicados pelas ações antrópicas ocorridas no entorno e vertentes do reservatório como concentração de matéria orgânica na água, deposição de resíduos domésticos, de animais e de lixo no manancial.

\section{CONSIDERAÇÕES FINAIS}

O reservatório Cajá destaca-se como um manancial importante para o município de Taboleiro Grande (RN), por ser uma fonte de abastecimento de água; entretanto algumas práticas socioeconômicas e ambientais tendem a degradar a qualidade de suas águas. O presente trabalho permitiu conhecer a realidade ambiental do reservatório, ficando evidente durante a pesquisa que o reservatório sofre com poluição antrópica em seu entorno, principalmente pela criação de animais e o lançamento de esgoto doméstico. Esse dano causado pelo homem ocasiona problemas no abastecimento hídrico do município, aumentado pelo baixo índice pluviométrico na região nos últimos anos.

Para que haja uso adequado do manancial, há a necessidade de elaboração um plano de manejo, no sentido de evitar a deterioração de suas águas, bem como uma sensibilização por parte da população local, visando a melhoria na qualidade das águas do reservatório, uma vez que o retorno será indispensável para a sociedade.

\section{REFERÊNCIAS}

BASSOI, L. J. Poluição das águas. In: PHILIPPI JÚNIOR, A.; PELICIONI, M. C. F. Educação ambiental e sustentabilidade. São Paulo: Manole, 2005. Cap.7, p.175-193.

BLOG TABOLEIRO GRANDE NEWS. Disponível em: $<$ www.taboleirograndenews.com.br>. Acesso em 15 de março de 2015.

BRAGA, B.; HESPANHOL, I.; CONEJO, J. G.; MIERZWA, J. C.; BARROS, M. T. L.; SPENCER, M.; PORTO, M.; NUCCI, N.; JULIANO, S.; EIGER, S. Introdução à engenharia ambiental. 2 ed. São. Paulo: Prentice Hall, 2005.

CAPOANE, V.; TIECHER, T.; SCHAEFER, G. L.; SANTOS, D. R. Impactos da suinocultura na qualidade da água da bacia hidrográfica do Arroio Caldeirão, Palmitinho, Rio Grande do Sul. Brazilian Geographical Journal: Geosciences and Humanities research medium, Ituiutaba, v.5, n.2, p.494-509, jul./dez. 2014.

CARNEIRO, F. M. Análise do estudo de impacto ambiental e qualidade da água: o caso do Açude Atalho - Brejo Santo. Ceará. Fortaleza, 2002. 15 p.

CONAMA. Conselho Nacional de Meio Ambiente. Resolução n. ${ }^{\circ}$ 274, de 29 de novembro de 2000. Define os critérios de balneabilidade em águas brasileiras. Revoga os artigos 26 e 34 da Resolução no 20/86 (revogada pela Resolução no 357/05). Diário Oficial da República Federativa do Brasil. Brasília, Seção 1, p. 70-71, 25 jan. 2001. 
CONAMA. Conselho Nacional de Meio Ambiente. Legislação Ambiental, Resolução n.01, de 23 de janeiro de 1986. Disponível em $<$ http://www.mma.gov.br/port/conama >. Acesso em 15 mar. 2015.

CONAMA. Conselho Nacional de Meio Ambiente. Resolução Conama n.302/2002. Brasília, 2002. Disponível em < http://www.mma.gov.br/port/conama / > . Acesso em 15 mar. 2015.

DARTORA, V.; PERDOMO, C. C.; TUMELERO, I. L. Manejo de dejetos suínos. Concórdia: EMBRAPA, Suínos e Aves, 1998.

ESTEVES, F. A. Fundamentos de limnologia. Rio de Janeiro: Interciências, 1998.

FURTADO, Z. N. C.; FURTATO, M. C.; CRESPI, R. S. F. Estudo prévio de viabilidade hidrogeoambiental face à vulnerabilidade do ambiente subterrâneo na implantação de um cemitério em Araçatuba-SP. Anais... Congresso Internacional de Meio Ambiente Subterrâneo. 2009.

IDEMA - Instituto de Desenvolvimento Econômico e Meio Ambiente. Perfil do seu município: Taboleiro Grande. Natal, 2008.

JORGE, C. M. B. P. Tratamento das águas residuais dos dejetos de suínos com aguapé, um estudo de caso no campus Nilo Peçanha-Pinheiral-RJ. Anais... Congresso Nacional de Excelência em Gestão, 9. Rio de Janeiro, junho de 2013.

MATOS, B. A. Avaliação ocorrência e do transporte de micro-organismos no aquífero freático do cemitério de Vila Nova Cachoeirinha município de São Paulo. 113 p. Tese (Doutorado) - Instituto de Geociências, Universidade de São Paulo, São Paulo, 2001.

MARTINS, T. M.; PELLIZARI, V. H.; PACHECO, A.; MYAKI, D.; ADAMS, C.; BOSSOLAN, N. R. S.; MENDES, J. M. B.; HASSUDA, S. (1991). Qualidade bacteriológica de águas subterrâneas em cemitérios. Revista Saúde Pública, São Paulo, v.25, p.47-52.

MIGLIORINI, R.B. et al. Qualidade das águas subterrâneas em áreas de cemitério. Região de Cuiabá - MT. Águas Subterrâneas, v.20, n.1, p.15-28, 2006.

MOSCA, A. A. O. Caracterização hidrológica de duas microbacias visando a identificação de indicadores hidrológicos para o monitoramento ambiental do manejo de florestas plantadas. Dissertação (Mestrado em Recursos Florestais) - Escola Superior de Agricultura Luiz de Queiroz, Piracicaba-SP, 2003.

MOTA, S. Planejamento urbano e preservação ambiental. Fortaleza: UFC-Proedi, 1981

NOGUEIRA, C. O. G.; COSTA JUNIOR, J. E. V.; COIMBRA, L. A. B. Cemitérios e seus Impactos Socioambientais no Brasil. Fórum Ambiental da Alta Paulista, v.9, n.11, 2013, p.331-344. Disponível em < http://www.academia.edu/ >. Acesso em 15 mar. 2015.

NOLASCO, M. A.; BAGGIO, R. B.; GRIEBELER, J. Implicações ambientais e qualidade da água da produção animal intensiva. Revista Acadêmica, Curitiba, v.3, n.2, p.19-26, 2005.

PEREIRA, E. R.; DEMARCHI, J. J. A. A.; BUDIÑO, F. E. L. A questão ambiental e os impactos causados pelos efluentes da suinocultura. 2009. Disponível em: $<$ http://www.infobibos.com/Artigos/2009 3/QAmbiental/index.htm $>$. Acesso em: $11 / 06 / 2015$ 
REBOUÇAS, A. C. Água doce no mundo e no Brasil. In: REBOUÇAS, A. C.; BRAGA, B.; TUNDISI, J. G. Águas doces no Brasil: capitais ecológicos usos e conservação. 3 ed. São Paulo: Escrituras, 2002. p.269-324

ROLIM, H. O.; LEITE JÚNIOR, J. B.; GOMES FILHO, R. R. Qualidade da água. In: GOMES FILHO, R. R. (Org.). Gestão de recursos hídricos: conceitos e experiências em bacias hidrográficas. Goiânia: UEG, 2013. p.217-235

SCHNEIDER, R.M.; FREIRE, R.; COSSICH, E. S. et. al. Estudo da influência do uso e ocupação de solo na qualidade da água de dois córregos da Bacia Hidrográfica do rio Pirapó. Acta Scientarium Technology. Maringá, v.33, n.3, p.295-303, 2011.

SEGANFREDO, M. A. A questão ambiental na utilização de dejetos de suínos como fertilizante do solo. Concórdia: Embrapa Suínos e Aves, Circular Técnica 22, 2000. 37 p.

SELBORNE, L. A ética do uso da água doce: um levantamento. Brasília: UNESCO, 2001. $80 \mathrm{p}$.

SILVA, D. F. Análise de aspectos climatológicos, ambientais, agroeconômicos e de seus efeitos sobre a Bacia hidrográfica do rio Mundaú (AL e PE). Tese de Doutorado em Recursos Naturais, Universidade Federal de Campina Grande, 2009.

SOUZA, J. R.; MORAES, M. E. B.; SONODA, S. L.; SANTOS, H. C. R. G. A importância da qualidade da água e os seus múltiplos usos: caso do Rio Almada, Sul da Bahia, Brasil REDE - Revista Eletrônica do Prodema, Fortaleza, v.8, n. 1, p.26-45, abr. 2014.

STRUJAK, D.; VIDAL, C. M. S. Poluição das águas - revisão da literatura. Revista Eletrônica Lato Sensu - Unicentro. Guarapuava, v.2, julho de 2007. Disponível em: $<$ http://web03.unicentro.br/especializacao/Revista > Acesso em: 25 maio 2015

IBGE - Instituto Brasileiro de Geografia e Estatística. Taboleiro Grande. Perfil do município. Disponível em: <http://www.cidades.ibge.gov.br>. Acesso em: 14 janeiro 2015.

TUCCI, C. E. M. (Org.). Hidrologia: ciência e aplicação. 3 ed. Porto Alegre: Editora da UFRGS; ABRH, 2004.

TUNDISI, J. G. Limnologia e manejo de represas. São Paulo: EESC

USP/CRHEA/ACIESP, 1998. 